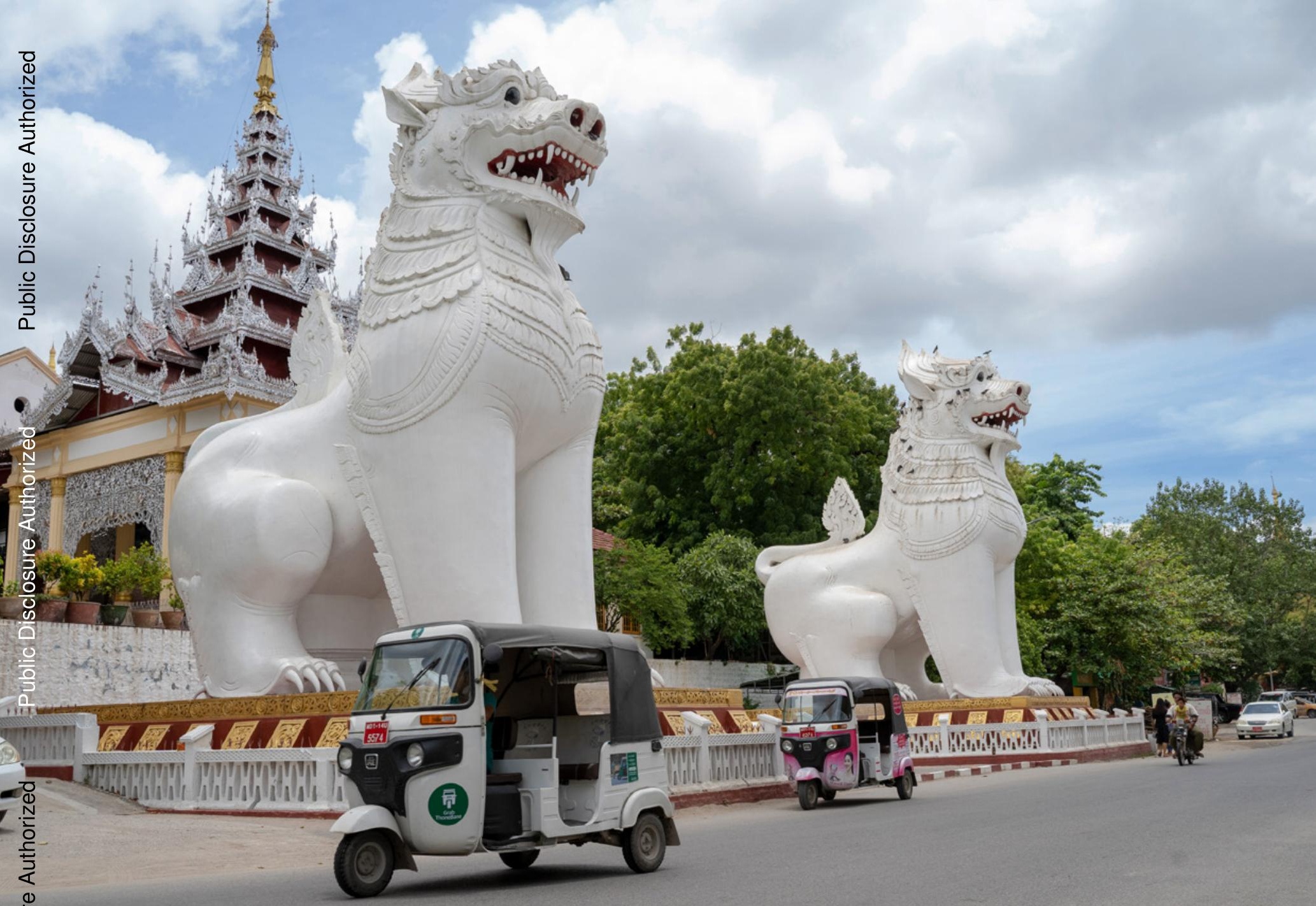

\title{
URBAN TRANSPORT IN MANDALAY
}

Institutions, Expenditures, and Funding

Myanmar Urban Mobility

Overview Notes 
$M$ andalay is the second-largest city in Myanmar and a gateway to the Bay of Bengal to neighboring economic hubs. Rapid economic and demographic growth, paired with the relaxation of import restrictions for new and used two, three and four-wheeler has resulted in rapidly declining conditions for urban transport. Motorization and vehicle intensity use, congestion, emissions, and traffic-related injuries are hampering well-being and competitiveness. Unless action is taken, Mandalay will consolidate as a motorcycle-only city, posing challenges for the excluded and vulnerable.

A people-centric, actionable, and financially viable strategy for sustainable urban mobility is one of the pillars for a prosperous, thriving, and sustainable bold vision for Mandalay over the next decade.

The World Bank recently issued a report on Urban Transport in Yangon and Mandalay. The report calls for urgent actions to seize the window of opportunity brought by a growing economy and put forward actionable, simple, and affordable strategies aiming to provide efficient, equitable, clean, and safe mobility for Myanmar' largest urban agglomerations.

This overview note presents highlights of the report for Mandalay. It could support policy discussions on $\mathrm{h}$ improving urban transport with proportional funding and financing and financing options suited to a bold vision for Mandalay.

This report has been co-funded by the Mobility and Logistics Multidonor Trust Fund (MOLO), managed by the World Bank Group and supported by the Governments of Switzerland (SECO), Germany (BMZ), and Austria (BMF).

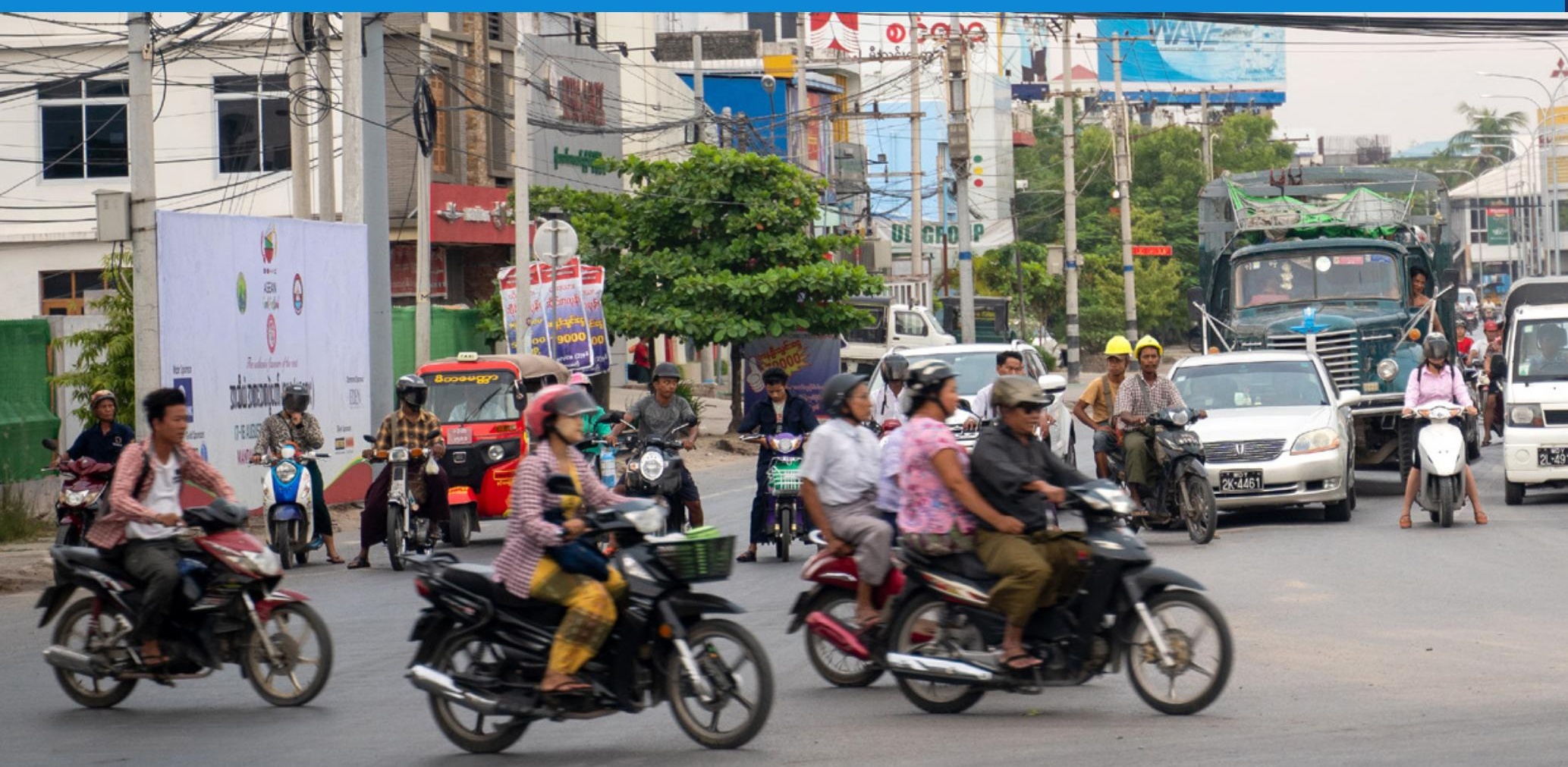


Mandalay, with an urban population of about 2.1 million, is the second-largest city in Myanmar. The Mandalay Region's total population is about 12 percent of the national population and its contribution to gross domestic product (GDP) is approximately 10 percent. Mandalay is located on the Greater Mekong Subregion (GMS) Northern Economic Corridor linking Myanmar with China and India. Mandalay's strategic geographic location helped it become an important trading center in Myanmar.

Mandalay has a comparatively small urban footprint and limited density. Built-up areas, including residential, commercial, and industrial areas, as well as public and transit areas, cover about 17 percent of land use in Mandalay City. The city dwellers meet most of their commuting needs with direct alternatives, favoring motorbike and walking. Since 2012, the city has experienced an exponential increase in motorization, after the government eased restrictions on car and motorcycle imports.

\section{Motorcycles dominate transport in Mandalay.} Data shows that motorcycles account for 70 percent of all trips, excluding walking (Figure 1). The Mandalay Region has 30 percent of the country's motorcycle registrations, with 688,652 registered motorcycles in the city alone $(1,182,691$ across the region, as of 2014). This equates to 2.12 motorcycles per household (0.16 for cars and 0.92 for bicycles) and a motorcycle ownership rate of about 400 per 1,000 inhabitants. The motorcycle ownership rate might appear high, but international comparisons indicate that it could still grow by 50 percent before reaching saturation point. Figure 2 illustrates that motorcycles are not only the largest category in vehicle registration but also the fastest-growing category yearon-year. Mandalay is expected to continue registering motorcycles at a higher rate than other types of vehicles.
Figure 1. Modal split in Mandalay, 2016 (ADB)

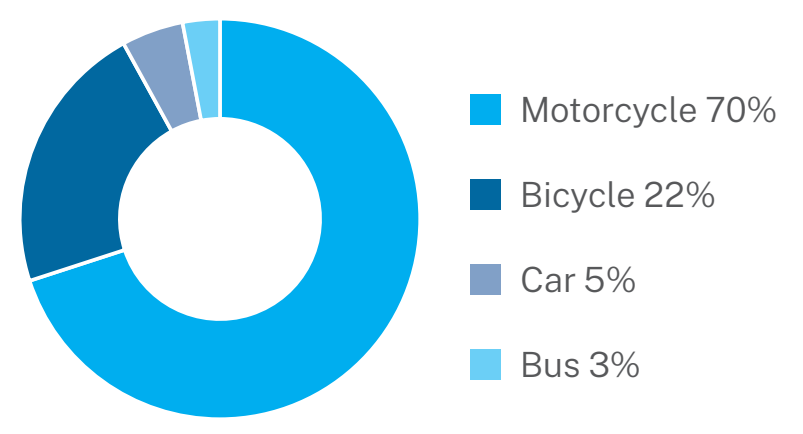

Figure 2. Growth in Registered Vehicles by Type in Mandalay. RTAD, 2018.

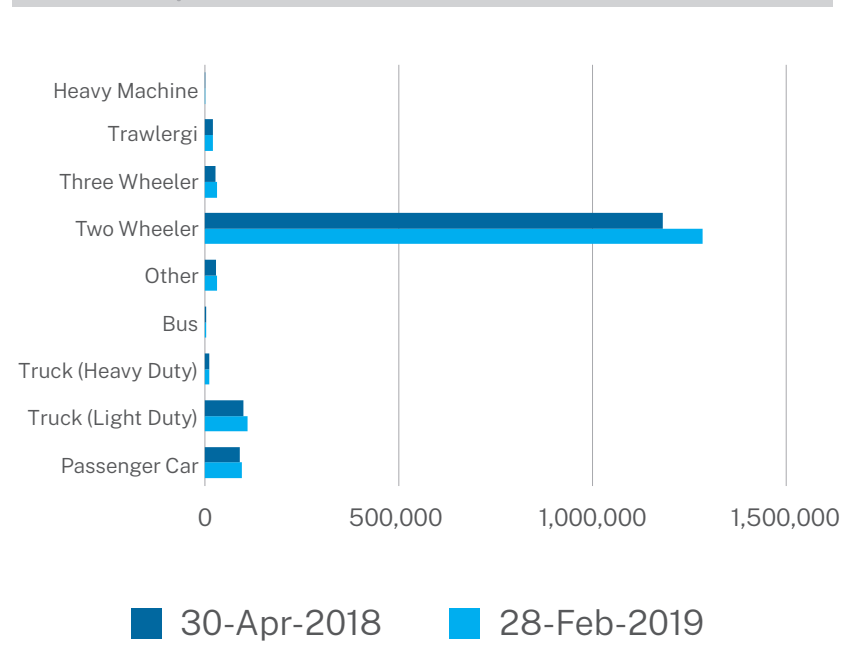

Buses play a minimal role in Mandalay's urban transport. In Mandalay, a very small group of bus users are captives of public transport. Public transport users tend to be citizens who carry voluminous packages to and from the markets and find it too expensive or cumbersome to travel with cargo on motorbikes. Public transport vehicles themselves are, difficult to access and, in general, not fit for the purpose. Ya ka ka, a legacy nongovernment organization (NGO), permits minibus operations with limited oversight. The existing system includes of 18 city buses ( 90,000 passengers per month); 383 Dyna (759,600 passengers per month); 15 Hilux (24,300 passengers per month); and 401 light 
trucks (686,700 passengers per month). Buses generally make three trips per day, with an average of 100 passengers per day (data from Ya ka ka interviews, 2018).

While the city has a train line and a central train station, the train line plays no urban transport function and, due to its slow and uncompetitive run times, has a limited regional capacity.

Mandalay, which used to be a city of bicycles, has limited bicycle use now. Easy access to motorbikes has meant that bicycles as commuter vehicles have all but vanished, and the limited infrastructure that used to exist for bicycles is now primarily used as parking space for motorbikes.

Increased motorization and lack of wellfunctioning urban transport systems undermine the future economic growth potential of the city, becoming a major burden on the mobility of the population and their access to jobs and services.

\section{PERFORMANCE REVIEW OF MANDALAY'S TRANSPORT SYSTEM}

Improvementsintransportinfrastructurebring tangible benefits to cities' competitiveness and quality of life. Performance targets can be used as an accountability mechanism for policymakers to objectively measure the impact of improvements on the transport system and provide a clear message to the public about the results and expectations for upcoming urban transport investments. First, Mandalay requires assessing what aspects of its urban transport system are in greatest need of improvement and whether reforms and investments are having the desired impact.

The performance review on Mandalay's transport system is based on selected indicators. Policy makers may consider these preliminary results to trace strategic goals for their transport systems, which should aim at lowering accident rates, travel times, and pollutant emissions, and maintaining a high modal share of motorized trips done by public transport.

A review of selected urban transport performance indicators provides unbiased, comparable information on positive aspects of public transport in Mandalay, as well as other aspects where regional peers show that there is substantial room for improvement. Mandalay ranks positively in aspects of affordability of public transport, which has direct linkages to social inclusion aspects. Other indicators, such as commuting times, road safety, and air quality, show that Mandalay has an important need for for strengthening and improving the quality of its urban mobility program.

Public transport modal share. The majority of its citizens have turned to motorcycles for their daily travel needs, and public transport plays a minimal role. Mandalay's public transport modal share, at 2 percent, is outstandingly low and only comparable to Ho Chi Minh City in Vietnam, which is a city dominated by motorcycles, with relatively adequate infrastructure for motorcycles. Considering the minimum role of public transport, a preliminary accessibility analysis to jobs and opportunities shows less than positive results.

Urban accessibility. The World Bank-standard analysis considers jobs accessible by public transport over a 60-minute window. Public transportation is very limited in Mandalay, 
and city residents commute to work mostly by motorbikes. In similar cities such as Kampala, Uganda, or Hanoi, Vietnam, accessibility analysis is favorable for public transport users. The same cannot be said about Mandalay, as the precarious network and frequencies do not provide adequate levels of accessibility to jobs or opportunities.

Traffic fatalities. In 2018, the World Health Organization estimated that Myanmar has one of the highest road crash-related fatalities in the region, estimated at 19.9 fatalities per 100,000 inhabitants. Road fatalities in Mandalay are among the highest in Myanmar, with around 39 fatalities per 100,000 inhabitants. Pedestrians and cyclists account for almost half of road fatalities in urban areas in Myanmar, which compares unfavorably to global road traffic deaths.

Figure 3. Road Fatalities per 100,000 Inhabitants (WHO 2018)

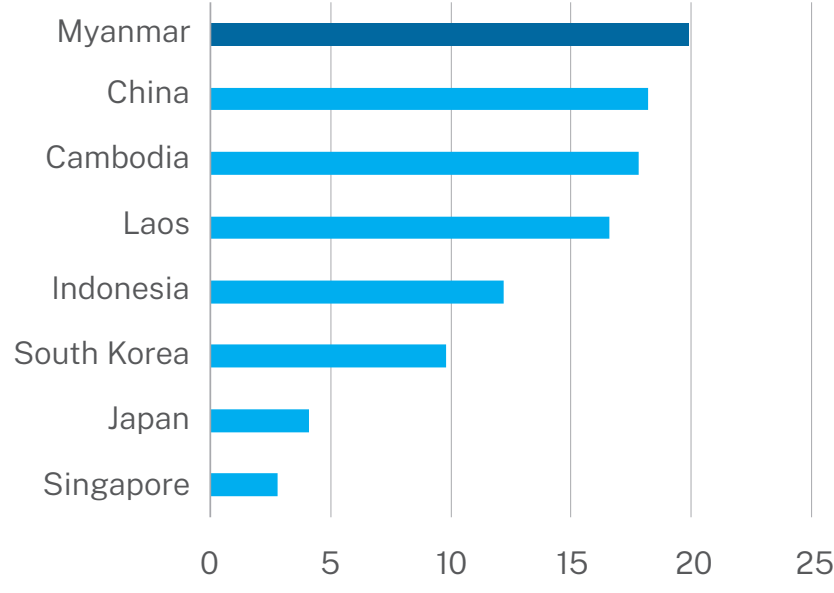

Air quality. Data suggests that air quality measurements in Mandalay reports an unsafe concentration of $\mathrm{PM}_{10}$, partly attributed to combustion emissions, suspended particulate matter from dust and seasonal organic material burning. Air quality is worse around industrial areas, sometimes tripling the WHO recommended level of $20 \mu \mathrm{g} / \mathrm{m}^{3}$.
Figure 4. Air Pollution in Selected Cities, $\mathrm{PM}_{10}$ Concentration ADB 2015; WHO 2016

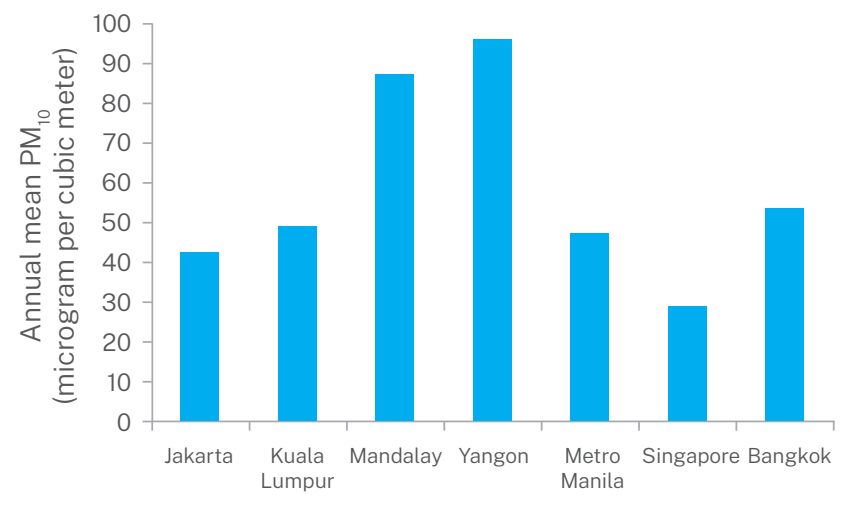

For Mandalay, the benchmarking of urban mobility indicators reveals mixed results and opportunities for action. Mandalay's first steps towards better urban mobility systems could introduce actionable, affordable and straightforward Avoid, Shift Improve strategies as part of its efforts to encourage nonmotorized trips, improve the quality of fuel and public transport vehicles (that is, compressed natural gas [CNG]), and air quality, and reduce pollution-related health risks. For traffic deaths, Mandalay should take urgent action to improve road safety and invest in actionable, affordable and straightforward Vision Zero strategies, which introduce infrastructure, vehicle and behavior improvements to minimize road safety risks, particularly for the most vulnerable road users.

Figure 5. Summary of Performance Review: Mandalay

\begin{tabular}{|l|c|}
\hline Commuting travel time & Poor \\
\hline Urban accessibility & Poor \\
\hline Public transport affordability & Good \\
\hline Public transport modal share & Poor \\
\hline Traffic fatalities & Moderate/Poor \\
\hline Air quality & Moderate/ Poor \\
\hline
\end{tabular}




\section{POLICY RECOMMENDATIONS}

The recommendations summarized in this note are based on a detailed analysis of the main report: Urban Transport in Yangon and Mandalay. They are organized into three strategic areas: (i) urban transport institutions and policy, (ii) urban transport financing and expenditures; and (iii) and urban transport funding, aiming to provide actionable urban mobility solutions and corresponding financing and funding options to advance towards sustainable urban mobility in Mandalay.

\section{Urban transport Institutions \& Policy}

Incomplete decentralization in Myanmar has so far led to institutional fragmentation, overlapping functions, and disjointed accountabilities in the transport sector. This particularly affects the ability of subnational governments to raise financing and funding for the sector, integrate different transport modes, and advance on high-level policies toward a sustainable urban mobility system. Poor coordination and fragmented responsibilities undermine the possibilities of advancing toward an integrated, efficient, and sustainable urban mobility system.

Mandalay lacks a dedicated transport authority, while the regulation of the existing bus system is under the mandate of the regional government. Buses in Mandalay are owned and operated by private entities, and there is a body for regulating services, Ya Ka $\mathrm{Ka}$. The Bus Supervisory Committee, headed by the Regional Minister, controls and manages bus operations in the city. It consists of elected representatives of bus associations, which in turn represent individual bus operators. There is a need to design and implement an integrated transport authority that could lead and coordinate the implementation of urban mobility plans for the city. This could be addressed by reviewing the practical operationalization of the decentralization in Mandalay to achieve a clearer distribution of responsibilities and remove the potential for duplication and dual reporting lines between the Mandalay Regional Government and the Mandalay City Development Committee (MCDC).

In Mandalay, there is a need to design and implement an integrated transport authority which could lead and coordinate the implementation of urban mobility plans for the city. Mandalay does not have a welldefined urban transport authority at the city level, and transport functions at the regional level focus primarily on roads and inter-city connectivity. A well-defined, technically competent, and adequately funded urban transport agency is the first cornerstone to advance with adequately-funded, sustainable urban mobility strategies. For that reason, Mandalay could advance in policy and action that allows establishing the Mandalay Regional Transport Authority --MRTA, which should gradually build technical capacity that will enable it to coordinate the development and implementation of urban transport strategies and policies as a lead agency. 


\section{The Mandalay Regional Transport} Authority could effectively advance in developing and implementing strategic urban transport plans around comprehensive 'push and pull' strategies.

Such strategies, aimed at disincentivizing private vehicle use (for example, reducing implicit subsidies to private transport --push) while boosting the attractiveness of sustainable transport modes (pull) by increasing access, coverage, and quality, have been successfully piloted in efforts to persuade urban dwellers to opt for sustainable transport alternatives over two-wheelers, which is overwhelmingly the favored mode at present. Both are significant challenges, which other comparable cities in the region have struggled to address but might nevertheless offer some useful lessons.

While the establishment of the MRTA should occur over the next two years, Mandalay should redouble as early as possible, its efforts in preserving and improving road space, including traffic management and traffic engineering measures. These simple, straightforward, and affordable actions should yield results and form a foundation for the implementation of more complex, strategic urban transport investments in the long term. Major infrastructure investments would require an enhanced financial structuring, possibly blending funding from the regional and union governments and financing at the municipal level.

Mandalay should also prioritize digital infrastructure to overcome the current lack of accurate and reliable transport and urban data. An updated and comprehensive urban transport survey would help better understand the citizens' travel behaviors. Public bus information such as geo-coded routes, frequencies, speeds, and bus fares is neither updated regularly nor available in accessible digital format. Data must be considered as an infrastructure-such as roads and rails-on which additional urban services can be provided using insights from transport analytics. Such a 'data-as-infrastructure' approach, if executed properly, will not only be equitable but can also bring financial growth due to economies of scale.

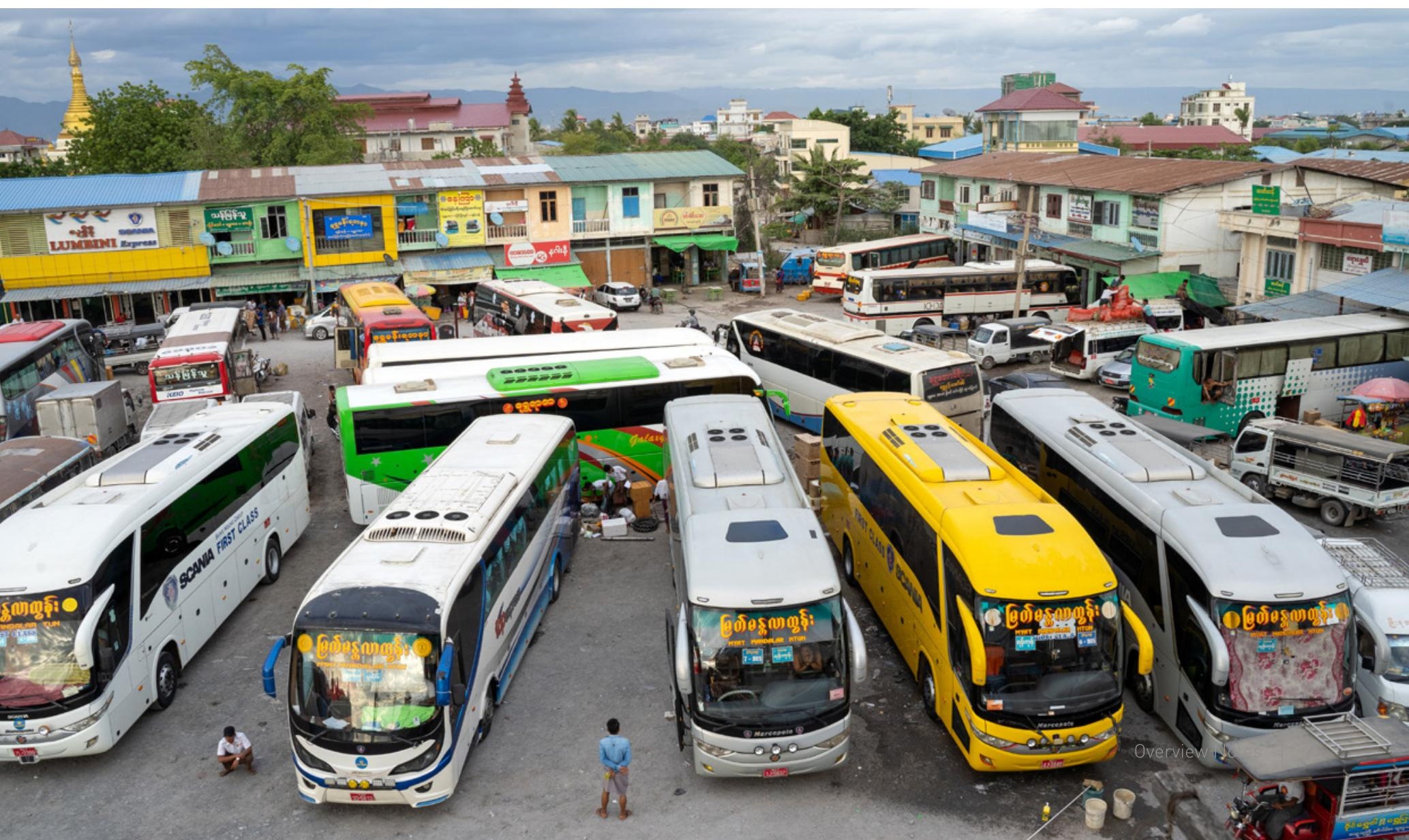




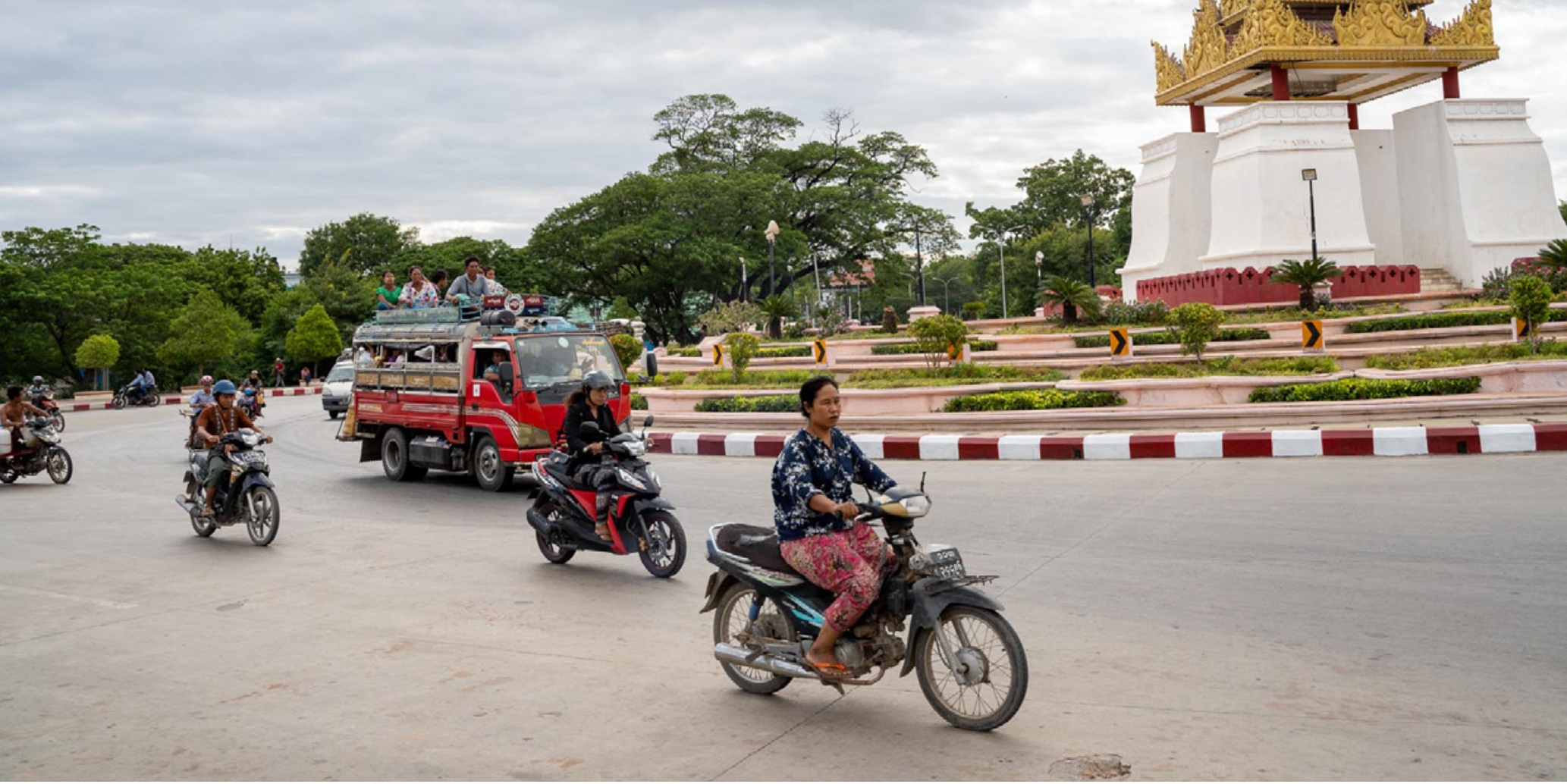

\section{Transport and Social Inclusion in Mandalay}

Spatial inclusion remains a challenge in urban areas of Myanmar, given high land and housing costs and the overall poor quality of basic infrastructure. Ethnicity, cultural norms and spatial exclusion disproportionately affect the mobility of marginalized groups.

Global evidence shows that promoting social inclusion and reducing inequality can make growth more resilient. Social stratification and exclusion from basic services, infrastructure, and economic opportunities can constrain productivity and trap marginalized groups in poverty.

Inclusion aspects of urban transport in Mandalay have not been researched in detail yet, and available data are limited. Articulating a comprehensive sustainable urban mobility strategy with broader sociallyinclusive policies is a double win, as inclusive transport systems have shown to play a big role in facilitating access to markets and business centers for excluded and vulnerable population groups, improving access to opportunities to income-generating opportunities, including employment, trade and markets, and social and capital networks.

Mandalay could advance with inclusive mobility policies is by considering complementary strategies addressing crime and violence, including transport-related instances of gender-based violence and sexual harassment. Additional measures are necessary to ensure that all population groups can equally access and benefit from inclusive public transport initiatives, such as accessible and safe pedestrian facilities for bus riders to get to and from bus stops and destinations, to ensure door-to-door accessibility and security. 


\section{SUMMARY OF RECOMMENDATIONS: URBAN TRANSPORT POLICY AND INSTITUTIONS}

\begin{tabular}{|c|c|c|c|}
\hline Issues and Gaps & Short Term (1-2 years) & Medium Term (2-3 years) & Long Term (3-5 years) \\
\hline $\begin{array}{l}\text { There is no formally } \\
\text { established public } \\
\text { transport authority, } \\
\text { and public } \\
\text { transport service } \\
\text { provision is very } \\
\text { limited. }\end{array}$ & $\begin{array}{l}\sqrt{ } \text { Establish an } \\
\text { integrated urban } \\
\text { transport authority } \\
\text { in Mandalay (at the } \\
\text { Regional level) and } \\
\text { begin developing } \\
\text { an urban mobility } \\
\text { strategy. }\end{array}$ & $\begin{array}{l}\sqrt{ } \text { Define adequate } \\
\text { funding and staffing } \\
\text { mechanisms for the } \\
\text { integrated urban } \\
\text { transport authority in } \\
\text { Mandalay. } \\
\sqrt{ } \text { Review results of the } \\
\text { preliminary strategy } \\
\text { to prioritize actions, } \\
\text { prioritize digital } \\
\text { infrastructure to } \\
\text { leapfrog and transform } \\
\text { into smart cities to } \\
\text { overcome current lack } \\
\text { of accurate and reliable } \\
\text { transport and urban } \\
\text { data }\end{array}$ & $\begin{array}{l}\sqrt{ } \text { Enact policy changes } \\
\text { and urban transport } \\
\text { investments in line with } \\
\text { the recommendations } \\
\text { of the urban mobility } \\
\text { strategy. } \\
\sqrt{ } \text { Set up indicators to } \\
\text { track impact of actions } \\
\text { and investments. }\end{array}$ \\
\hline $\begin{array}{l}\text { Mandalay: improve } \\
\text { social inclusiveness } \\
\text { of their transport } \\
\text { systems to more } \\
\text { equitably serve the } \\
\text { needs of all groups } \\
\text { including, persons } \\
\text { with disabilities } \\
\text { (PwDs), women, } \\
\text { children, the elderly } \\
\text { and others. }\end{array}$ & $\begin{array}{l}\sqrt{ } \text { Identify higher- } \\
\text { level regulatory and } \\
\text { strategic planning } \\
\text { activities that should } \\
\text { be supported by } \\
\text { a metropolitan } \\
\text { transport regulatory } \\
\text { agent. }\end{array}$ & $\begin{array}{l}\sqrt{ } \text { Enact policy-level } \\
\text { actions through } \\
\text { understanding specific } \\
\text { mobility needs of } \\
\text { excluded and socially } \\
\text { vulnerable groups. }\end{array}$ & $\begin{array}{ll}\sqrt{ } & \text { Integrate inclusiveness } \\
& \text { analysis into urban } \\
& \text { transport policies and } \\
& \text { plans } \\
\sqrt{ } & \text { Set up indicators to } \\
& \text { track impact of actions } \\
& \text { and investments. } \\
\sqrt{ } & \text { Monitor results of } \\
& \text { policy-level actions }\end{array}$ \\
\hline
\end{tabular}

\section{Urban Transport Expenditures}

\section{Public sector intervention in public transport} has a sound basis in economic theory. Private car users do not consider the costs they impose on other road users and non-road users in terms of increased congestion and pollution. There is a role for governments in correcting these negative externalities through increasing the price of road use and through subsidies to public transport, which is more efficient in its use of road space and less polluting on a per passenger basis.

\section{There is no financing plan for urban transport} in Mandalay. Discussions are ongoing to develop an urban transport master plan for Mandalay with the support of the Korea International Cooperation Agency (KOICA). While preparation and approval of such a plan is likely to take time, Mandalay would also need to implement interim actions including establishment of an integrated urban transport authority, preservation and improvement of existing roads, including traffic management 
and traffic engineering measures, which require limited financing but could yield results and form a foundation for implementation of larger investments. Major infrastructure investments would require substantial financing from the regional and union governments, which should be prioritized and assessed during the preparation of the master plan.

Interim solutions may be required to prioritize spending for the immediate needs of the city based on available financing and funding space. The current financing and funding capacity is constrained, and there are significant institutional and capacity weaknesses on project appraisal and preparation. Therefore, robust prioritization of investment is important. Mandalay could consider prioritizing spending in road and sidewalk rehabilitation together with improved urban transport institutional arrangements, which could serve the immediate needs of the sector with high benefit potential. Priority should also be given to preserving current assets and improving the maintenance of roads by putting in place a functioning asset management system. Major investments in infrastructure upgrading should be carefully considered in terms of public spending and matched with realistic and financing and funding capacity and instruments.

Review of sector expenditures indicates that public spending level in urban transport is not enough to meet the high demand for transport service delivery. Doubling of expenditure on roads as a share of regional GDP, from the current 0.7 percent to around 1.5 percent, is recommended in the medium to long term. The impact of underspending can already be seen in Mandalay, where road traffic congestion and traffic injuries are on the rise as citizens with growing incomes turn to private two-, three-, and four-wheelers.

Alongside increases in expenditure on urban transport, efficiency improvements will be required for budgeting and public investment management. Efficiency improvements alone will not close the significant gap in urban transport infrastructure and services but getting more outputs from a given expenditure will nevertheless play an important part in making expenditure increases go further in delivering better outcomes in terms of more productive cities and improved mobility for the population.

The use of public-private partnerships (PPPs) may unlock financing for improving and expanding urban transport infrastructure and services. PPPs are still public projects, even if the procurement and financing modality is different; therefore, they should not be to be tagged as a panacea but must be treated with caution because significant specialist skills are required to negotiate a good deal on behalf of the public sector. PPPs can also pose a significant fiscal risk, either explicitly or implicitly. A poorly performing project from a societal perspective will remain unviable, whether it is implemented through a traditional or a PPP modality; PPPs, therefore, need to be subject to the same tests as any other public investment project to determine whether they will deliver net welfare benefits to society. 
SUMMARY OF RECOMMENDATIONS: URBAN TRANSPORT POLICY AND INSTITUTIONS

\begin{tabular}{|c|c|c|c|}
\hline ssue & Short Term (1-2 years) & Medium Term (2-3 years) & Long Term (3-5 years) \\
\hline $\begin{array}{l}\text { Fragmented } \\
\text { responsibilities in } \\
\text { sector financing } \\
\text { and expenditure } \\
\text { planning }\end{array}$ & $\begin{array}{ll}\sqrt{ } & \text { Institute more } \\
\text { systematic data } \\
\text { collection on volume } \\
\text { and quality of } \\
\text { outputs from public } \\
\text { expenditure on } \\
\text { urban transport, as } \\
\text { a starting point for a } \\
\text { stronger efficiency } \\
\text { orientation. }\end{array}$ & $\begin{array}{l}\sqrt{ } \text { Adopt a comprehensive } \\
\text { view of urban transport } \\
\text { expenditures planning } \\
\text { - treating it as a unified } \\
\text { policy area, rather than } \\
\text { devising policies mode by } \\
\text { mode. } \\
\sqrt{ } \text { Improve the alignment } \\
\text { between the urban } \\
\text { transport sector } \\
\text { expenditure and revenue } \\
\text { assignments. }\end{array}$ & $\begin{array}{l}\sqrt{ } \text { Remove the gaps in } \\
\text { the legislative design } \\
\text { of the decentralization } \\
\text { to achieve a clearer } \\
\text { distribution of fiscal } \\
\text { responsibilities in the } \\
\text { sector. } \\
\sqrt{ } \text { Strengthen the fiscal } \\
\text { responsibilities for the } \\
\text { sector at the subnational } \\
\text { level, remove the } \\
\text { duplication and dual } \\
\text { reporting lines. }\end{array}$ \\
\hline $\begin{array}{l}\text { Constrained } \\
\text { fiscal capacity } \\
\text { compared with } \\
\text { high financing } \\
\text { needs }\end{array}$ & $\begin{array}{ll}\sqrt{ } \text { Prioritize road } \\
\text { maintenance } \\
\text { expenditures and } \\
\text { improve efficiency } \\
\text { in maintenance } \\
\text { practices. } \\
\sqrt{ } \text { On capital expendi- } \\
\text { tures, prioritize those } \\
\text { projects which can } \\
\text { relieve or forestall } \\
\text { traffic congestion } \\
\text { with lower cost as } \\
\text { traffic engineering } \\
\text { and traffic manage- } \\
\text { ment solutions. }\end{array}$ & $\begin{array}{ll}\sqrt{ } \text { Introduce formal } \\
\text { procedures and rigorous } \\
\text { analysis methods for } \\
\text { appraisal of major urban } \\
\text { transport projects. } \\
\sqrt{ } \text { Improve capacities } \\
\text { to apply investment } \\
\text { appraisal procedures and } \\
\text { methods. } \\
\sqrt{ } \text { Leverage private sector } \\
\text { financing by piloting } \\
\text { first; risks related to such } \\
\text { transactions should be } \\
\text { carefully considered in } \\
\text { deciding PPP projects. }\end{array}$ & $\begin{array}{l}\sqrt{ } \text { Gradually increase } \\
\text { public expenditure on } \\
\text { urban transport by up } \\
\text { to } 1.5-2.0 \text { percent of } \\
\text { regional GDPs. } \\
\sqrt{ } \text { Develop appropriate } \\
\text { institutional } \\
\text { arrangements and } \\
\text { technical capacities for } \\
\text { PPPs to enable private } \\
\text { financing for major PPPs } \\
\text { in the sector. }\end{array}$ \\
\hline
\end{tabular}

\section{Funding and Financing Strategies}

In Myanmar there is no dedicated funding to urban transport, although some instruments currently exist. Existing funding instruments include property tax, bus management fee (with Ya ka ka in Mandalay), parking charges, wheel tax and special goods tax on fuel. None of these funding sources are dedicated to urban transport or broader transport.

Advancing with an actionable, affordable and sustainable urban mobility strategy for Mandalay requires dedicated revenue streams for the region and city governments that are relatively stable and predictable over the long term. Long-range capital plans are only useful and practical when revenue and budgets for infrastructure development are relatively stable and reliable and come from dedicated revenues sources such as property taxes, parking charges, fuel-related taxes, long-range union, or regional infrastructure spending programs. Mandalay should consider the following to enhance funding for the improvement of its transport systems. 


\section{Four recommendations to Mandalay for enhancing funding for the improvement of urban transport systems}

1. To develop resource mobilization plans for the urban transport system. Such plans can review types of instruments in place to finance and fund different urban transport system components and review them from the perspective of revenue level, financial and transport sustainability, and the beneficiary type.

2. To use the existing funding instruments to enhance funding capacity at subnational levels. Mandalay could start with mobilizing funding to urban transport through the existing funding instruments such as property tax, wheel tax, and parking fees. Conservative estimations indicate that Mandalay has the potential to generate over US\$1.3 billion between 2020 and 2035 with the existing funding instruments, which can be earmarked to fund urban transport systems. Revenues generated from these instruments could help support the immediate priorities.

3. To explore new funding instruments with sufficient assessment of benefits and risks. New instruments such as fuel excise tax or land value capture schemes can be potentially considered to expand the urban transport funding space. Regarding fuel excise tax, a thorough feasibility study can be implemented to analyze the economic and social impacts, proper apportionment scheme to the region and city, consideration of the profile of consumers, and minimizing of the negative impact on the poor and vulnerable groups. For land value capture, subnational governments could consider establishing a framework with institutional and regulatory coordination that enables operationalizing and piloting such a mechanism as part of the investment plans of urban transport development. Operationalizing land value capture requires defining the links of the allocation of land development to the urban transport infrastructure and service delivery.

4. To prioritize new infrastructure projects based on their social and economic benefits and potential to generate revenues to finance capital and operational costs. The prioritization needs to consider the financial viability of the projects, which involves an assessment of the cost management and revenue generation of the projects. Revenues generated from urban transport projects include road tolls, fare revenue, and non-fare revenues generated from advertising, land leasing, and so on.

Unless Mandalay introduces push and pull measures to nudge urban dwellers into public transport and non-motorized modes, isolated investments in public transport will not guarantee immediate results. Consequently, investing in urban mobility requires a comprehensive, step-by strep strategy paired with the fiscal capacity of the government. As public budgets must respond to diverse public service needs, the governments should identify various funding sources and instruments for the urban transport sector, to advance towards sustainable and inclusive urban transport system to serve the needs of all groups of the population. 


\section{SUMMARY OF RECOMMENDATIONS: URBAN TRANSPORT FUNDING}

\begin{tabular}{|c|c|c|c|}
\hline s & Sho & s) & s) \\
\hline $\begin{array}{l}\text { Inadequate } \\
\text { funding results } \\
\text { in deteriorating } \\
\text { quality of } \\
\text { urban transport } \\
\text { services. } \\
\text { While mobility } \\
\text { demand is } \\
\text { growing, } \\
\text { resources } \\
\text { remain } \\
\text { insufficient to } \\
\text { maintain and } \\
\text { improve the } \\
\text { urban transport } \\
\text { system. }\end{array}$ & $\begin{array}{l}\sqrt{ } \text { Develop resource } \\
\text { mobilization plans } \\
\text { for the urban } \\
\text { transport system and } \\
\text { improve institutional } \\
\text { coordination } \\
\text { required for resource } \\
\text { mobilization. } \\
\sqrt{ } \text { Prioritize new } \\
\text { urban transport } \\
\text { projects based on } \\
\text { their potential to } \\
\text { generate revenues to } \\
\text { finance capital and } \\
\text { operational costs. }\end{array}$ & $\begin{array}{l}\sqrt{ } \text { Use the existing non- } \\
\text { fare funding instruments } \\
\text { (wheel tax, property tax, } \\
\text { special goods tax on fuel } \\
\text { and parking charges) to } \\
\text { enhance funding capacity } \\
\text { for the sector at the } \\
\text { subnational level. } \\
\sqrt{ } \text { Consider establishing } \\
\text { mechanism of revenue } \\
\text { allocation from the } \\
\text { abovementioned } \\
\text { instruments to urban } \\
\text { transport development, } \\
\text { with supporting fiscal } \\
\text { and budget policies from } \\
\text { the national government. }\end{array}$ & $\begin{array}{l}\sqrt{ } \text { Explore new funding } \\
\text { instruments for the } \\
\text { sector such as land value } \\
\text { capture and fuel-based } \\
\text { taxes and surcharges with } \\
\text { support from the national } \\
\text { government on supportive } \\
\text { fiscal policies and } \\
\text { institutional coordination. } \\
\sqrt{ } \text { When considering new } \\
\text { revenue sources such as } \\
\text { fuel tax, carry out detailed } \\
\text { analysis of their economic } \\
\text { and social impacts and } \\
\text { options to reduce negative } \\
\text { impacts on the poor } \\
\text { before implementation. }\end{array}$ \\
\hline
\end{tabular}




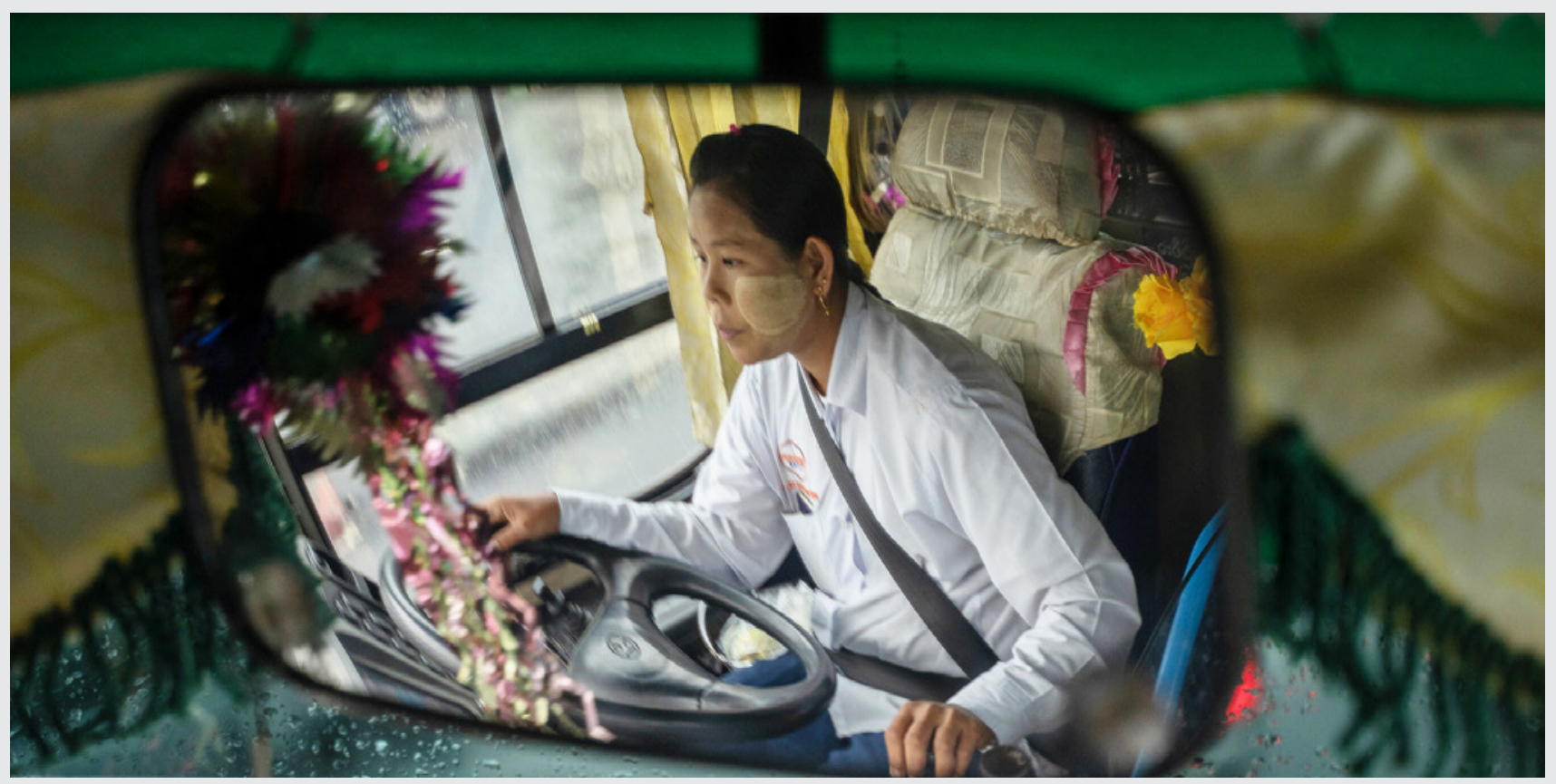

Report No: AUS0001291

(c) 2020 The World Bank

1818 H Street NW, Washington DC 20433

Telephone: 202-473-1000; Internet: www.worldbank.org

Photos, including cover picture: World Bank, 2019

Some rights reserved

This work is a product of the staff of The World Bank. The findings, interpretations, and conclusions expressed in this work do not necessarily reflect the views of the Executive Directors of The World Bank or the governments they represent. The World Bank does not guarantee the accuracy of the data included in this work. The boundaries, colors, denominations, and other information shown on any map in this work do not imply any judgment on the part of The World Bank concerning the legal status of any territory or the endorsement or acceptance of such boundaries.

\section{Rights and Permissions}

This work is available under the Creative Commons Attribution 4.0 IGO license (CC BY 4.0 IGO)

\section{(c) (i)}

Under the Creative Commons Attribution license, you are free to copy, distribute, transmit, and adapt this work, including for commercial purposes, under the following conditions: Attribution-Please cite the work as follows: World Bank Group. Urban Transport in Mandalay Overview. Washington, DC: World Bank Group. License: Creative Commons Attribution CC BY 4.0 IGO.

All queries on rights and licenses should be addressed to World Bank Publications, The World Bank Group, 1818 H Street NW, Washington, DC 20433, USA; e-mail: pubrights@worldbank.org. 